\title{
Effect of Water Regime on the Sucrose-Enzyme Relationships of Sugarcane Desiccated with Paraquat'
}

\author{
Rafael Montalvo-Zapata and Alex G. Alexander ${ }^{2}$
}

\section{INTRODUCTION}

The bipyridylium herbicides Paraquat ${ }^{3}$ and Diquat ${ }^{4}$ have aroused increasing interest among sugarcane growers throughout the world $(19,21,22,30)$. They have been used successfully for weed control, preharvest desiccation, and flower control $(1,13,15,20,28)$. However, until quite recently their mode of action in sugarcane has not been closely examined.

In 1967, studies were initiated at this Station to investigate sugar and enzyme changes which parallel chemical desiccation $(8,9)$. It was shown that Paraquat and Diquat restrict photosynthesis while increasing the activity of several metabolic enzymes. These changes are usually reflected in lower cane quality (7), but some of the undesirable effects have been alleviated by incorporating silicon into the plant as a foliar pretreatment (10).

Important questions persist concerning the ecological and physiological limitations within which bipyridyl desiccants are effective. Their relative efficiency in wet and dry climates is unknown. Pronounced differences in the activity of Paraquat or Diquat in clear and cloudy weather are only partially understood. In addition, the persistence of desiccant effects upon sugar content and enzyme behavior remains obscure.

Water regime is unquestionably an important factor in sugar synthesis, transport, and storage $(14,24)$. Whether water supply per se can alter the drying action of Paraquat or Diquat is doubtful; yet nothing has appeared in the literature to sustain this assumption. The experiment reported herein was designed to clarify the effects of water regime on moisture, sugar and enzyme changes in sugarcane treated with Paraquat.

\section{EXPERIMENTAL PROCEDURE}

\section{GROWTH AND TREATMENT OF PLANT MATERIALS}

A single greenhouse experiment was conducted with the interspecific variety P.R. 980. Plants were grown in $\mathrm{HCl}$-washed quartz and contained

1 Submitted to the Editorial Board September 24, 1971.

2 Assistant Chemist and Plant Physiologist, respectively, Agricultural Experiment Station, University of Puerto Rico, Mayagüez Campus, Rio Piedras, P.R.

s 1,1'-dimethyl-4,4-dipyridinium-bis-dimethyl sulfate, commercially known as Gramaxone.

46,7-dihidrodipyrido $\left(1,2-a: 2^{\prime}, 1^{\prime}-c\right)$ pyrazidinium salt, commercially known as Reglone. 
in 2-gallon stoneware pots. Each container received 1 liter of a complete nutrient solution ${ }^{6}$ plus an equal amount of tapwater daily until treatments were begun at 16 weeks of age. Three levels of water and two of Paraquat were then given in factorial combinations. A randomized block design was employed with three replicates for each treatment. Water was supplied at rates of 1,2 , and 4 liters per day. Under sand-culture conditions 1 liter provides insufficient water and induces ripening; 2 liters provide a normal regime, and 4 liters are excessive without creating flood conditions. Three weeks after variable water regimes were initiated, Paraquat was applied once as a 0.05 -percent aqueous foliar spray. Tween- 20 ( 0.10 percent) was included as wetting agent and all above-sand portions of the plants were sprayed until runoff began.

Tissue samples were harvested for sugar and enzyme analyses at 1, 3, and 9 days after desiccant application. Leaf and immature storage tissues were quick-frozen in a mixture of dry ice and acetone and stored in a freezer. They were lyophilized and ground to pass a 60 -mesh screen prior to extraction. Leaf sheaths were retained for moisture determinations and millable stalks were ground with a small laboratory mill for Brix and polarization analyses. Samples of milled juice were preserved in the freezer for sucrose analysis by direct colorimetry.

\section{LABORATORY ANALYSES}

Clarified aqueous extracts of the tissue powder were analyzed for sucrose by the resorcinol method of Cardini et al. (18). Aliquot samples of milled juice were clarified in a centrifuge and analyzed for sucrose following additional clarification with $\mathrm{Ba}(\mathrm{OH})_{2}$ and $\mathrm{ZnSO}_{4}$.

Protein was precipitated from water extracts with solid ammonium sulfate at room temperature and $\mathrm{pH}$ 7.0. Protein yield was increased by chilling the solutions for 30 minutes at $4^{\circ}-6^{\circ} \mathrm{C}$. The 0-80-percent fraction was used for enzyme analyses following 2-hour dialysis against two changes of distilled water. Acid phosphatase and ATP-ase were measured in accordance with methods described earlier (2), as were invertase (3), amylase (4), polyphenol oxidase (5), and peroxidase (6). All enzyme assays were completed within 3 days after tissue extraction. The technique of Sutherland et al. (32) was used to measure the protein content of enzyme preparations. Enzyme action was computed as specific activity (activity units per mg. of protein).

Biochemicals were purchased from the Nutritional Biochemicals Corpora-

5 Nutrient concentrations, expressed as milliequivalents per liter, were provided as follows: Nitrate, 10; phosphate, 6; potassium, 5; calcium, 3; magnesium, 2; and sulfate, 2. Microelements, expressed as parts per million, were given as follows: Boron, 0.05; copper, 0.02; manganese, 0.50; zinc, 0.05; molybdenum, 0.01 ; and iron, 1.0. 
tion, Cleveland, Ohio. Gramaxone (Paraquat) was supplied by local representatives of the Chevron Chemical Company, Ortho Division.

All replicated data were submitted to statistical analysis of variance and mean values were analyzed by the Duncan new multiple range test. Summaries of significant mean differences are presented in tables 1,2 , and 3 . Quality values for milled juice were obtained with combined samples and are treated empirically in the text.

\section{RESULTS AND DISCUSSION}

\section{GROWTH RESPONSES TO VARIABLE WATER AND PARAQUAT}

After 3 weeks of variable irrigation the low-water plants had become moderately stunted and light green in color. Medium- and high-water plants retained a deep-green color and appeared to produce gains in total fresh weight and stalk weight (table 4). At the first harvest, 1 day after Paraquat application, mean fresh-weight and stalk-weight values were significantly greater in the high-water regime than in the low-water regime (table 1).

General wilting and color changes from green to olive green were recorded 24 hours after spraying with Paraquat. By 72 hours the plants were severely wilted, although overcast skies had retarded Paraquat activity. Sheath moisture content did not decline appreciably until after the second harvest, at 3 days (table 4). By 9 days the leaf, leaf-sheath, and spindle tissues were completely desiccated. The sheath moisture decline in Paraquat-treated plants was consistent and highly significant among all water regimes (table 1).

The decline of total fresh weight in desiccating plants was alleviated significantly at 3 days by the intermediate- and high-water regimes; however, by 9 days no appreciable moderating effects were evident. A similar trend was shown by stalk weights (table 1). It is probable that, under greenhouse conditions with excellent chemical coverage, higher-water regimes can do no more than delay desiccation. Under field conditions where chemical penetration is at best marginal, highly turgid plants might reduce the chemical's overall effectiveness.

Gumbs (23), in Guyana, has suggested that moisture content may increase in stalks of desiccant-treated cane owing to continued water uptake at $a$ time when normal transpiration is no longer possible. The present study does not support this contention. Examination of stalk weights at 9 days after Paraquat application showed that high water had significantly increased stalk weight where no Paraquat was applied, but no increases were obtained in desiccated cane (fig. 1, table 1).

In general, green-weight responses to Paraquat were of lesser magnitude 
$\mathrm{T}_{\mathrm{ABLE}}$ 1.-Summary of significant mean differences among green-weight and sugar values for sugarcane treated with three levels of water and two levels of Paraquat in sand culture ${ }^{1}$

\begin{tabular}{|c|c|c|c|c|c|c|c|}
\hline \multirow{2}{*}{ Parameter } & \multicolumn{3}{|c|}{ Days } & \multirow{2}{*}{ Parameter } & \multicolumn{3}{|c|}{ Days } \\
\hline & 1 & 3 & 9 & & 1 & 3 & 9 \\
\hline Total fresh weight & $\begin{array}{l}4 p>1 p^{*} \\
4 p>2 p^{*} \\
4 p>1^{*}\end{array}$ & $\begin{array}{r}4>1 p^{*} \\
2 p>1 p^{*} \\
2>1 p^{*} \\
4 p>1 p^{*}\end{array}$ & $\begin{aligned} 4 & >4 p^{* *} \\
4 & >2 p^{* *} \\
4 & >1^{* *} \\
4 & >1 p^{* *} \\
2 & >1 p^{* *} \\
2 & >4 p^{* *} \\
2 & >2 p^{* *} \\
1 & >1 p^{* *} \\
2 & >1^{*} \\
2 p & >1 p^{*}\end{aligned}$ & $\begin{array}{l}\text { Leaf sucrose } \\
\text { Immature stem }\end{array}$ & $\begin{array}{l}4>2 \mathrm{p}^{* *} \\
4>4 \mathrm{p}^{* *} \\
2>2 \mathrm{p}^{* *} \\
1>2 \mathrm{p}^{* *} \\
2>4 \mathrm{p}^{* *} \\
1>4 \mathrm{p}^{* *}\end{array}$ & $\begin{array}{l}1>2 \mathrm{p}^{* *} \\
1>1 \mathrm{p}^{* *} \\
1>4 \mathrm{p}^{* *} \\
2>2 \mathrm{p}^{* *} \\
2>1 \mathrm{p}^{* *} \\
2>4 \mathrm{p}^{* *}\end{array}$ & $\begin{array}{l}4>1 \mathrm{p}^{* *} \\
4>2 \mathrm{p}^{* *} \\
4>4 \mathrm{p}^{* *} \\
1>1 \mathrm{p}^{* *} \\
1>2 \mathrm{p}^{* *} \\
1>4 \mathrm{p}^{* *} \\
2>1 \mathrm{p}^{* *} \\
2>2 \mathrm{p}^{* *} \\
2>4 \mathrm{p}^{* *} \\
1>4^{* *}\end{array}$ \\
\hline Stalk weight & & $\begin{aligned} 2 p & >1 p^{* *} \\
4 p & >1 p^{* *} \\
2 & >1 p^{* *} \\
4 & >1 p^{* *}\end{aligned}$ & $4>1^{*}$ & sucrose & $\begin{aligned} 1 p & >4 p^{* *} \\
1 & >4^{*} \\
1 & >4^{*} \\
2 p & >4^{*}\end{aligned}$ & $\begin{array}{l}4 p>1^{* *} \\
4 p>2^{* *} \\
2 p>4^{* *} \\
2 p>1^{* *}\end{array}$ & $\begin{aligned} 1 & >2^{* *} \\
1 p & >4^{*} \\
1 p & >2^{*} \\
2 p & >4^{*}\end{aligned}$ \\
\hline Sheath moisture & & & $\begin{array}{l}1>1 \mathrm{p}^{* *} \\
1>2 \mathrm{p}^{* *} \\
1>4 \mathrm{p}^{* *} \\
2>1 \mathrm{p}^{* *} \\
2>2 \mathrm{p}^{* *} \\
2>4 \mathrm{p}^{* *} \\
4>1 \mathrm{p}^{* *} \\
4>2 \mathrm{p}^{* *} \\
4>4 \mathrm{p}^{* *}\end{array}$ & & & $\begin{array}{l}1 p>4^{* *} \\
1 p>1^{* *} \\
4 p>1 p^{*} \\
4 p>2 p^{*} \\
2 p>2^{*} \\
1 p>2^{*}\end{array}$ & $\begin{array}{l}2 p>2^{*} \\
4 p>4^{*} \\
4 p>2^{*}\end{array}$ \\
\hline
\end{tabular}

1 The abbreviations and symbols used to prepare this table are defined as follows: The numerals 1 , 2, and 4 represent water regimes of 1, 2, and 4 liters per day. The letter $p$ indicates that foliar Paraquat was also given. One asterisk denotes a significant mean difference at the 5-percent level, and two asterisks denote significance at the 1-percent level. For illustration, the notation $4 p>1 p^{*}$, appearing at the top of the table for total fresh weight indicates that plants receiving the 4-liter regime plus Paraquat were found to be heavier than plants receiving 1 liter plus Paraquat, and that the mean difference was significant at the 5-percent level. 


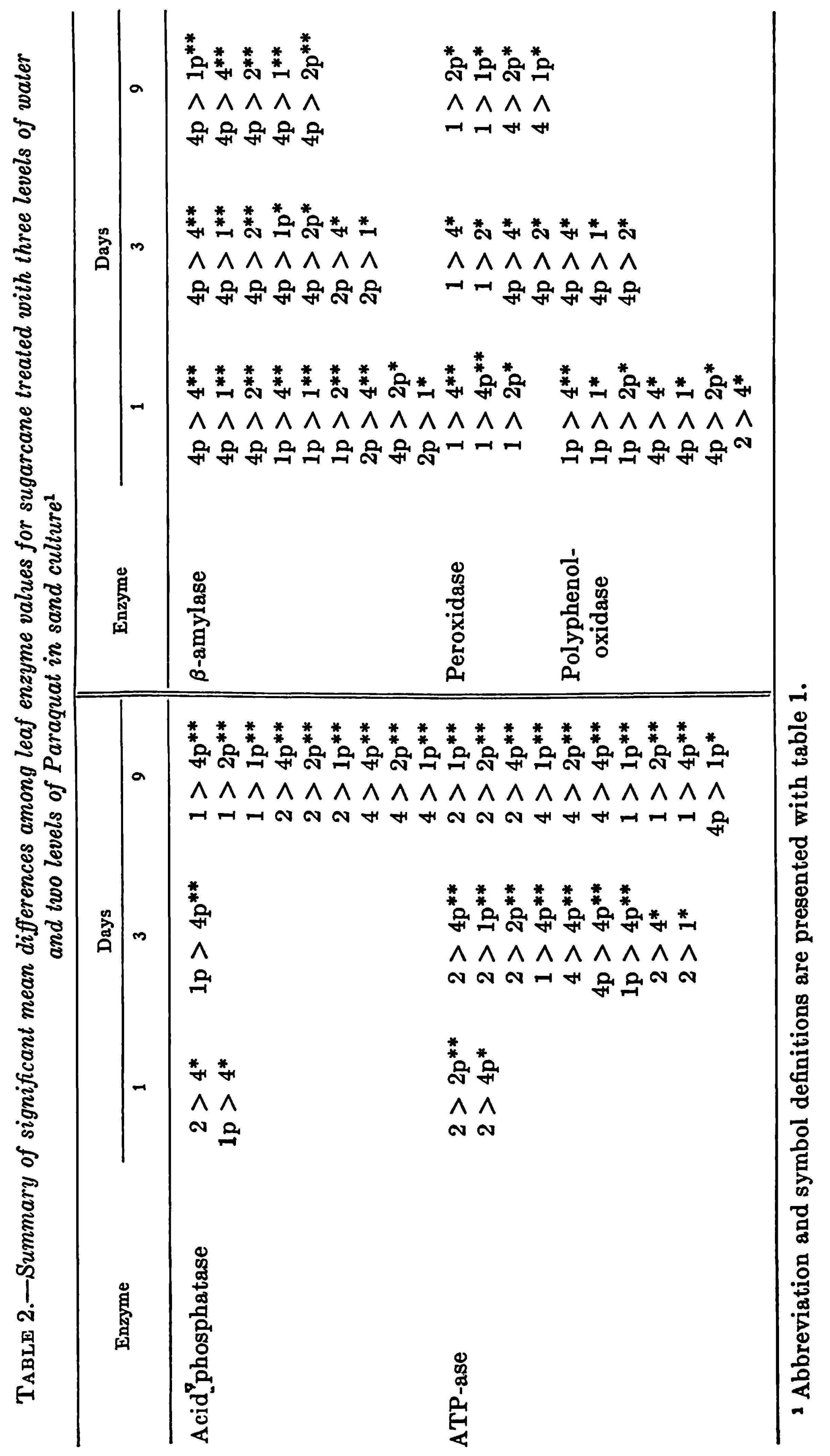




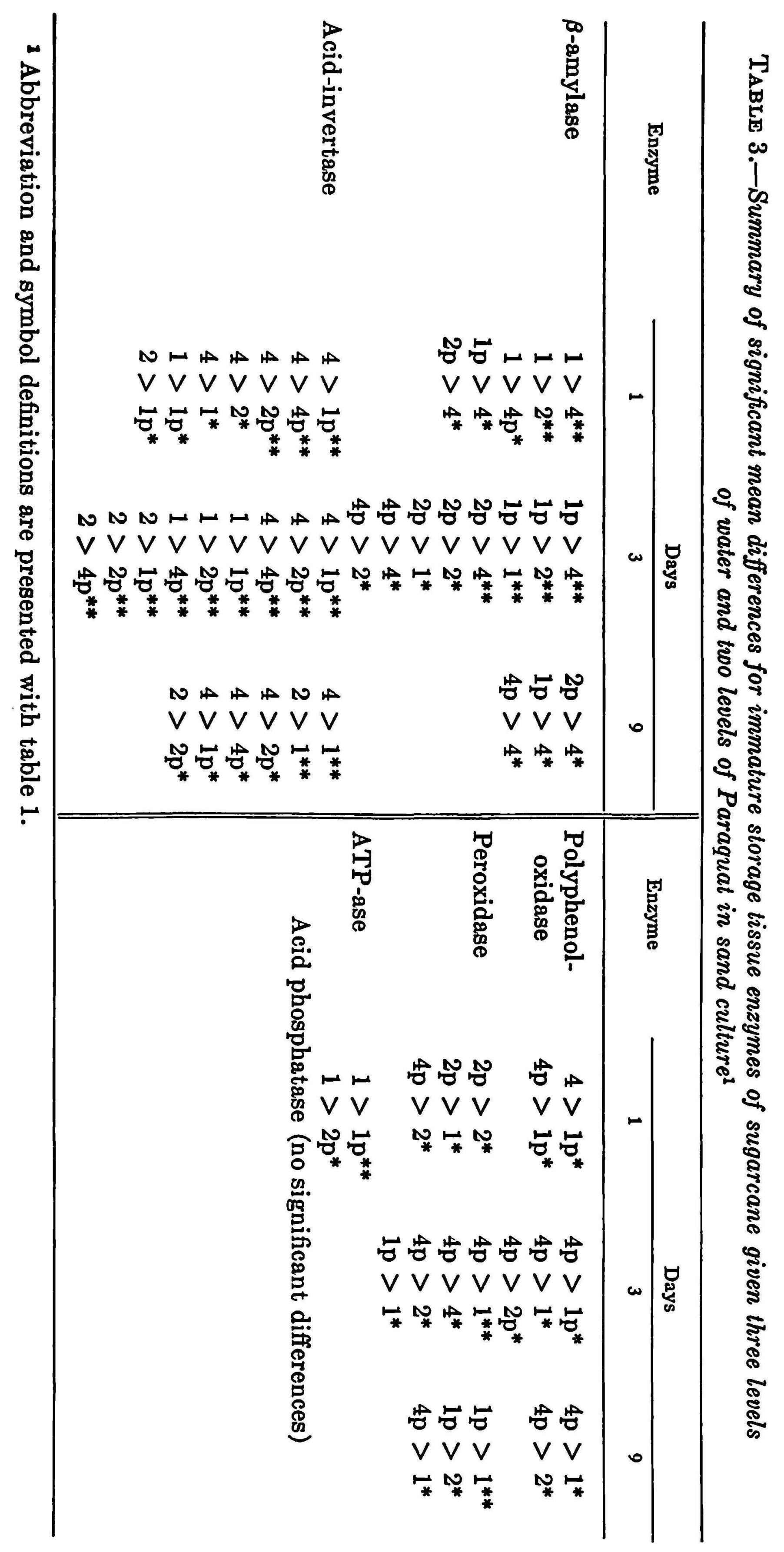

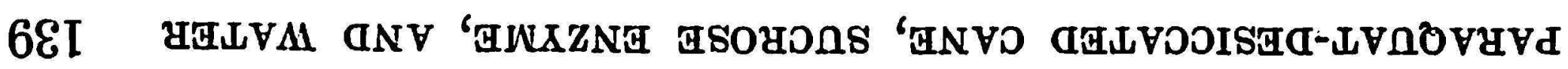


TABLE 4.-Weight and moisture values for sugarcane supplied with variable waler in sand culture and sprayed with variable Paraqual'

\begin{tabular}{|c|c|c|c|c|c|c|}
\hline \multirow{2}{*}{ Parameter } & \multirow{2}{*}{$\begin{array}{c}\text { Paraquat } \\
\text { (Percent } \\
\text { solution) }\end{array}$} & \multirow{2}{*}{$\begin{array}{l}\text { Water } \\
\text { (Liter/ } \\
\text { day) }\end{array}$} & \multicolumn{3}{|c|}{ Days after Paraquat application- } & \multirow{2}{*}{ Mean } \\
\hline & & & 1 & 3 & 9 & \\
\hline \multirow[t]{8}{*}{ Total fresh weight (g./plant) } & $\mathbf{0}$ & 1 & 192 & 190 & 183 & 188 \\
\hline & & 2 & 263 & 218 & 240 & 240 \\
\hline & & & & 224 & 264 & \\
\hline & Mean & & 230 & 211 & 229 & \\
\hline & 0.05 & 1 & 191 & 148 & 100 & 146 \\
\hline & & 2 & 203 & 223 & 156 & 194 \\
\hline & & 4 & 288 & 206 & 139 & 211 \\
\hline & Mean & & 227 & 192 & 132 & \\
\hline \multirow[t]{8}{*}{ Stalk weight (g./stalk) } & 0 & 1 & 53 & 55 & 50 & 53 \\
\hline & & 2 & 76 & 71 & 84 & 77 \\
\hline & & 4 & 69 & 69 & 94 & 77 \\
\hline & Mean & & 66 & 65 & 76 & \\
\hline & 0.05 & 1 & 53 & 35 & 66 & 51 \\
\hline & & 2 & 56 & 76 & 72 & 68 \\
\hline & & 4 & 84 & 71 & 67 & 74 \\
\hline & Mean & & 64 & 61 & 68 & \\
\hline \multirow[t]{8}{*}{ Sheath moisture (\%) } & $\mathbf{0}$ & 1 & 84.5 & 83.2 & 84.3 & 84.0 \\
\hline & & 2 & 83.2 & 82.4 & 83.3 & 83.0 \\
\hline & & 4 & 83.7 & 82.9 & 81.1 & 82.6 \\
\hline & Mean & & 83.8 & 82.8 & 82.9 & \\
\hline & 0.05 & 1 & 84.4 & 83.9 & 53.2 & 73.8 \\
\hline & & 2 & 85.0 & 83.3 & 50.0 & 72.7 \\
\hline & & 4 & 85.4 & 83.0 & 50.7 & 73.0 \\
\hline & Mean & & 84.9 & 83.4 & 51.3 & \\
\hline
\end{tabular}

${ }^{1}$ Each figure is the computed mean of three replicates.

at the intermediate-water level than when water supply was either low or excessive (table 4). This is consistent with earlier findings showing that high- and low-water stresses produce essentially similar growth responses in immature sugarcane (12). 


\section{SUGAR RESPONSES}

In Paraquat-free plants, leaf sucrose content did not vary significantly among the different water regimes (table 1 ). This implies that even 1 liter per day was sufficient to maintain both photosynthesis and sugar transport to storage tissue. Hartt (24) reported that low moisture supply depressed translocation of photosynthate more severely than the formation of photosynthate in the sugarcane leaf. Plants treated with Paraquat rapidly

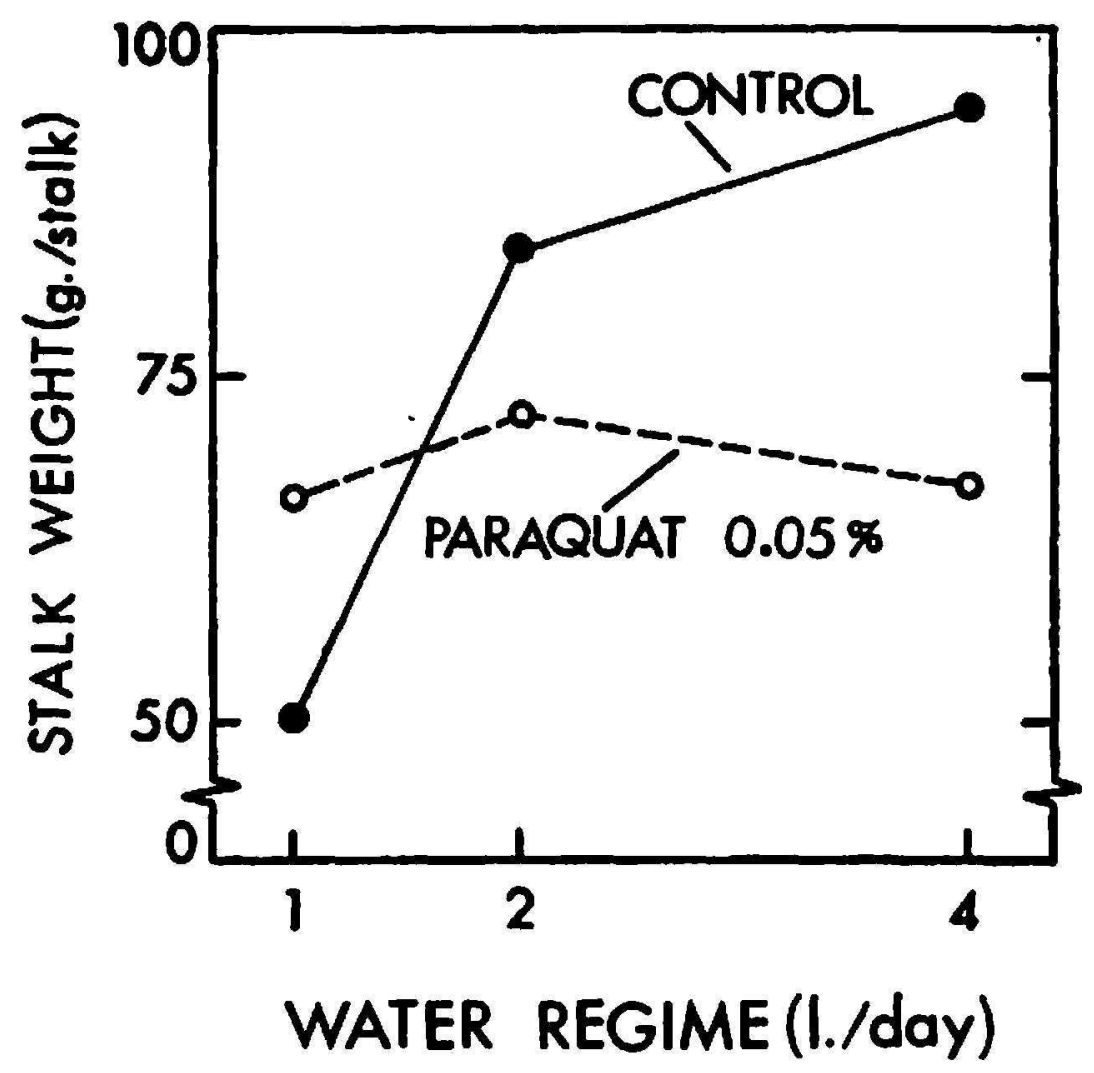

FrG. 1.-Effects of variable water regime on stalk weights of immature sugarcane propagated in sand culture. Plants treated with Paraquat were essentially insensitive to water differentials; Paraquat-free plants increased stalk weights with increasing water supply.

lost their foliar sucrose (fig. 2), the decline being highly significant by the third day among all water regimes (table 1). During the initial stages of desiccation (table 5, 1-day after treatment), leaf sucrose declined more rapidly within the 2-and 4-liter regimes than in the low-water regime. However, as was true of green-weight losses, water regime per se appears to have only a brief and limited capability to alleviate sucrose decline under greenhouse conditions.

Sucrose content of immature storage tissue was affected both by water regime and Paraquat (table 5). Significantly greater amounts of sucrose were present in the 1-liter regime than in the 4-liter regime at the initial 
harvest, regardless of Paraquat treatment (table 1). This was also true at 9 days in Paraquat-free plants; however, desiccated plants no longer showed the water-regime effect. Considerably more striking was the increase of sucrose levels in storage tissue of desiccating plants while leaf sucrose was declining to trace amounts (table 5). This is taken as evidence of continued sucrose transport out of the leaves after Paraquat had restricted production of new photosynthate. How the sucrose movement continued within the worsening water status of the leaves is difficult to explain in view of the importance that Hartt (24) has attached to water for sugar translocation.
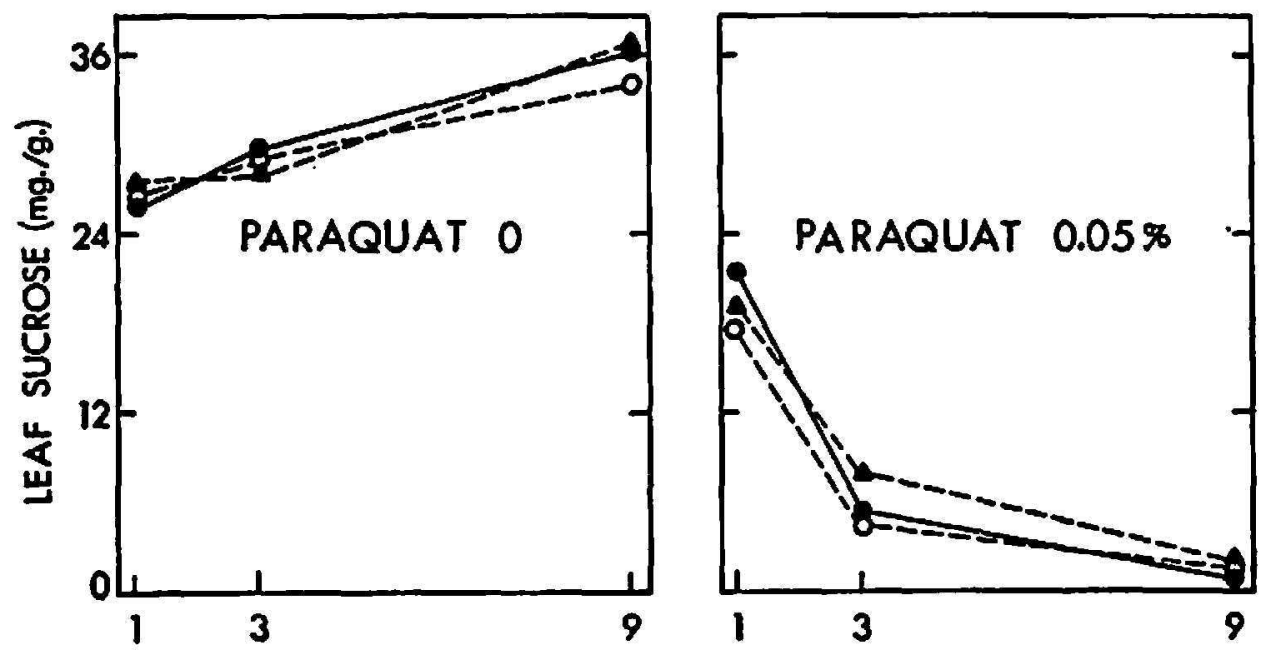

DAYS AFTER TREATMENT

Frg. 2.- Leaf sucrose content of immature sugarcane supplied with variable water in sand culture and sprayed with an aqueous Paraquat solution. Water regime had little effect on sucrose content in the absence of Paraquat (left), and failed to modify appreciably the sucrose losses produced by Paraquat (right). Symbols: (๑) 1 liter of water per day; (O) 2 liters per day; (A) 4 liters per day.

Possibly much of the increased sucrose in immature storage tissue came from the leaf sheaths or mature storage areas. In any event, storage sucrose levels must eventually decline when photosynthetic processes are rendered inoperative. The essential challenge remains one of protecting the photosynthesis unit from desiccant destruction while retaining the chemical's ripening potential (9). There is no evidence at present that controlled water supply is a suitable means to this end.

Quality parameters for milled juice generally reflect the loss of sugarforming capability of desiccated leaves (table 6). Although no statistical analyses were performed, the 9-day samples showed a repression of Brix, pol, and sucrose values in the Paraquat-treated cane. This verifies earlier results (9) and is consistent with Davidson (20) who reported Brix decline 4 days after desiccant application. These effects were general among all 
water regimes. However, the sucrose losses tended to be less severe where only 1 liter of water was given daily. Again, this is suggestive that abundant water supply will not restrain the detrimental effects of Paraquat on cane quality. Sucrose depletion in stalks of desiccated plants may be accountable in part to stimulation of invertase and amylase (see ENZYME RESPONSES),

TABLE 5.-Sucrose content of sugarcane supplied with variable water in sand cullure, and sprayed with variable Paraqual ${ }^{1}$

\begin{tabular}{|c|c|c|c|c|c|c|}
\hline \multirow{2}{*}{ Tissue } & \multirow{2}{*}{$\begin{array}{l}\text { Paraquat } \\
\text { (Percent } \\
\text { solution) }\end{array}$} & \multirow{2}{*}{$\begin{array}{l}\text { Water } \\
\text { (Liter/ } \\
\text { day) }\end{array}$} & \multicolumn{3}{|c|}{ Days after Paraquat application- } & \multirow{2}{*}{ Mean } \\
\hline & & & 1 & 3 & 9 & \\
\hline & & & & /E. of tis. & & \\
\hline \multirow[t]{8}{*}{ Leaf } & $\mathbf{0}$ & 1 & 25.7 & 30.8 & 36.0 & 30.8 \\
\hline & & 2 & 26.2 & 29.2 & 33.6 & 29.7 \\
\hline & & 4 & 26.8 & 28.8 & 36.4 & 30.7 \\
\hline & Mean & & 26.2 & 29.6 & 35.3 & \\
\hline & 0.05 & 1 & 20.7 & 4.7 & 0.8 & 8.7 \\
\hline & & 2 & 16.4 & 3.6 & 1.1 & $\mathbf{7 . 0}$ \\
\hline & & 4 & 17.6 & 7.0 & 1.5 & 8.7 \\
\hline & Mean & & 18.2 & 5.1 & 1.1 & \\
\hline \multirow{8}{*}{$\begin{array}{l}\text { Immature stor- } \\
\text { age }\end{array}$} & 0 & 1 & 179 & 170 & 247 & 199 \\
\hline & & 2 & 179 & 189 & 176 & 181 \\
\hline & & 4 & 149 & 169 & 170 & 163 \\
\hline & Mean & & 169 & 176 & 198 & \\
\hline & 0.05 & 1 & 190 & 218 & 230 & 213 \\
\hline & & 2 & 171 & 222 & 226 & 206 \\
\hline & & 4 & 159 & 248 & 223 & 210 \\
\hline & Mean & & 173 & 229 & 226 & \\
\hline
\end{tabular}

1 Each figure is the computed mean of three replicates.

but it is also possible that Paraquat increased the movement of sucrose to less mature storage tissues.

\section{ENZYME RESPONSES}

Foliar enzymes showed considerable sensitivity to the variable water and Paraquat treatments (table 7). ATP-ase was severely repressed in Paraquattreated plants, the effect being highly significant at the 3- and 9-day periods (table 2). Some workers contend that chloroplast ATP-ases catalyze partial 

JOURNAL OF AGRICULTURE OF UNIVERSITY OF PUERTO RICO

TABLE 6.-Brix, polarization and sucrose values for milled juice of sugarcane given variable water in sand cullure and sprayed with variable Paraquat ${ }^{1}$

\begin{tabular}{|c|c|c|c|c|c|c|}
\hline \multirow{2}{*}{ Parameter } & \multirow{2}{*}{$\begin{array}{l}\text { Parsquat } \\
\text { (Percent } \\
\text { solution) }\end{array}$} & \multirow{2}{*}{$\begin{array}{l}\text { Water } \\
\text { (Liter/ } \\
\text { day) }\end{array}$} & \multicolumn{3}{|c|}{ Days after Paraquat application- } & \multirow{2}{*}{ Mean } \\
\hline & & & 1 & 3 & 9 & \\
\hline \multirow[t]{8}{*}{ Brix } & \multirow[t]{3}{*}{$\mathbf{0}$} & 1 & 7.0 & 6.9 & 7.0 & 7.0 \\
\hline & & 2 & 6.9 & 8.0 & 7.1 & 7.3 \\
\hline & & 4 & 7.5 & 6.5 & 6.7 & 6.9 \\
\hline & \multicolumn{2}{|l|}{ Mean } & 7.1 & 7.1 & 6.9 & \\
\hline & \multirow[t]{3}{*}{0.05} & 1 & 7.0 & 7.4 & 5.1 & 6.5 \\
\hline & & 2 & 5.2 & 6.2 & 4.4 & 5.5 \\
\hline & & 4 & & 5.9 & & \\
\hline & \multicolumn{2}{|l|}{ Mean } & 6.4 & 6.5 & 4.8 & \\
\hline \multirow[t]{9}{*}{ Polarization } & \multirow[t]{3}{*}{0} & 1 & 13.8 & 8.0 & 15.9 & 12.6 \\
\hline & & 2 & 13.4 & 8.4 & 15.7 & 12.7 \\
\hline & & 4 & 17.8 & 5.9 & 13.3 & 12.3 \\
\hline & \multicolumn{2}{|l|}{ Mean } & 15.0 & 7.4 & 15.0 & \\
\hline & \multirow[t]{3}{*}{0.05} & 1 & 14.9 & 8.0 & 7.9 & 10.3 \\
\hline & & 2 & 8.3 & 9.3 & 5.2 & 7.6 \\
\hline & & 4 & 12.9 & 8.2 & 6.1 & 9.1 \\
\hline & \multicolumn{2}{|l|}{ Mean } & 12.0 & 8.5 & 6.4 & \\
\hline & \multirow{4}{*}{$\mathbf{0}$} & & \multicolumn{3}{|c|}{ (ms./ml. of juice) } & \\
\hline \multirow{8}{*}{ Sucrose } & & 1 & 71.4 & 55.6 & 72.4 & 66.5 \\
\hline & & 2 & 78.0 & 76.0 & 86.4 & 80.1 \\
\hline & & 4 & 93.0 & 70.6 & 79.0 & 80.9 \\
\hline & \multicolumn{2}{|l|}{ Mean } & 80.8 & 67.4 & 79.3 & \\
\hline & \multirow[t]{3}{*}{0.05} & 1 & 74.8 & 80.0 & 69.8 & 71.5 \\
\hline & & 2 & 49.4 & 60.6 & 41.8 & 50.6 \\
\hline & & 4 & 78.0 & 51.4 & 44.8 & 61.1 \\
\hline & \multicolumn{2}{|l|}{ Mean } & 67.4 & 66.0 & 48.0 & \\
\hline
\end{tabular}

1 Each figure is the computed mean of three replicates.

reactions of photosynthetic phosphorylation $(16,29)$, a view consistent with the sugarcane ATP-ase response and the expected loss of photosynthetic phosphorylation under these conditions $(26,27)$. An effect of water regime was also evident at 3 days when the ATP-ase decline was signif- 
TABLE 7.-Specific activity values for leaf enzymes of sugarcane supplied with variable water in sand culture, and treated with foliar Paraquat ${ }^{1}$

\begin{tabular}{|c|c|c|c|c|c|c|}
\hline \multirow{2}{*}{ Enzyme } & \multirow{2}{*}{$\begin{array}{c}\text { Paraquat } \\
\text { (Percent } \\
\text { solution) }\end{array}$} & \multirow{2}{*}{$\begin{array}{l}\text { Water } \\
\text { (Liter/ } \\
\text { day) }\end{array}$} & \multicolumn{3}{|c|}{ Days after Paraquat application- } & \multirow{2}{*}{ Mean } \\
\hline & & & 1 & 3 & 9 & \\
\hline \multirow[t]{4}{*}{ Phosphatase } & 0 & $\begin{array}{l}1 \\
2 \\
4\end{array}$ & $\begin{array}{l}26.2 \\
30.2 \\
22.9\end{array}$ & $\begin{array}{l}28.6 \\
29.4 \\
27.5\end{array}$ & $\begin{array}{l}32.9 \\
29.5 \\
26.0\end{array}$ & $\begin{array}{l}29.2 \\
29.7 \\
25.5\end{array}$ \\
\hline & Mean & & 26.4 & 28.5 & 29.5 & \\
\hline & 0.05 & $\begin{array}{l}1 \\
2 \\
4\end{array}$ & $\begin{array}{l}29.9 \\
25.6 \\
23.9\end{array}$ & $\begin{array}{l}32.5 \\
27.2 \\
22.0\end{array}$ & $\begin{array}{l}11.5 \\
11.0 \\
10.8\end{array}$ & $\begin{array}{l}24.6 \\
21.2 \\
18.9\end{array}$ \\
\hline & Mean & & 26.4 & 27.2 & 11.1 & \\
\hline \multirow[t]{4}{*}{ ATP-ase } & 0 & $\begin{array}{l}1 \\
2 \\
4\end{array}$ & $\begin{array}{l}36.3 \\
41.7 \\
32.2\end{array}$ & $\begin{array}{l}34.5 \\
44.7 \\
31.2\end{array}$ & $\begin{array}{l}36.2 \\
40.1 \\
36.3\end{array}$ & $\begin{array}{l}35.7 \\
42.2 \\
33.2\end{array}$ \\
\hline & Mean & & 36.7 & 36.8 & 37.5 & \\
\hline & 0.05 & $\begin{array}{l}1 \\
2 \\
4\end{array}$ & $\begin{array}{l}32.5 \\
25.6 \\
29.8\end{array}$ & $\begin{array}{l}26.4 \\
26.5 \\
18.1\end{array}$ & $\begin{array}{r}7.6 \\
12.4 \\
7.7\end{array}$ & $\begin{array}{l}22.1 \\
21.5 \\
18.5\end{array}$ \\
\hline & Mean & & 29.3 & 23.7 & 9.2 & \\
\hline \multirow[t]{4}{*}{$\beta$-amylase } & 0 & $\begin{array}{l}1 \\
2 \\
4\end{array}$ & $\begin{array}{l}41.6 \\
41.7 \\
29.8\end{array}$ & $\begin{array}{l}39.2 \\
42.5 \\
37.8\end{array}$ & $\begin{array}{l}44.6 \\
35.1 \\
29.2\end{array}$ & $\begin{array}{l}41.8 \\
39.8 \\
32.0\end{array}$ \\
\hline & Mean & & 37.4 & 39.8 & 36.3 & \\
\hline & 0.05 & $\begin{array}{l}1 \\
2 \\
4\end{array}$ & $\begin{array}{l}65.2 \\
57.7 \\
75.3\end{array}$ & $\begin{array}{l}61.3 \\
65.1 \\
93.9\end{array}$ & $\begin{array}{l}27.3 \\
48.0 \\
94.8\end{array}$ & $\begin{array}{l}51.3 \\
56.9 \\
88.0\end{array}$ \\
\hline & Mean & & 66.1 & 73.4 & 56.7 & \\
\hline \multirow[t]{3}{*}{ Peroxidase } & $\mathbf{0}$ & $\begin{array}{l}1 \\
2 \\
4\end{array}$ & $\begin{array}{l}65.3 \\
49.2 \\
35.2\end{array}$ & $\begin{array}{l}72.4 \\
44.2 \\
43.6\end{array}$ & $\begin{array}{l}58.9 \\
40.5 \\
54.4\end{array}$ & $\begin{array}{l}65.5 \\
44.6 \\
44.4\end{array}$ \\
\hline & Mean & & 49.9 & 53.4 & 51.2 & \\
\hline & 0.05 & $\begin{array}{l}1 \\
2 \\
4\end{array}$ & $\begin{array}{l}49.1 \\
41.1 \\
39.1\end{array}$ & $\begin{array}{l}54.3 \\
55.4 \\
72.1\end{array}$ & $\begin{array}{l}22.4 \\
12.2 \\
40.6\end{array}$ & $\begin{array}{l}41.9 \\
36.2 \\
50.6\end{array}$ \\
\hline
\end{tabular}


TABLE 7-Continued

\begin{tabular}{lcc|ccc|c}
\hline Enzyme & $\begin{array}{c}\text { Paraquat } \\
\text { (Percent } \\
\text { solution) }\end{array}$ & $\begin{array}{c}\text { Water } \\
\text { (Liter) } \\
\text { day) }\end{array}$ & \multicolumn{2}{|c|}{ Days after Paraquat application- } & \multirow{2}{*}{ Mean } \\
& Mean & & 43.1 & 3 & 9 & \\
\hline Tyrosinase & 0 & 1 & 20.5 & 25.5 & 25.7 & 23.9 \\
& & 2 & 26.7 & 27.0 & 22.8 & 25.5 \\
& 4 & 19.5 & 25.4 & 27.3 & 24.1 \\
\hline & Mean & & 22.2 & 26.0 & 25.3 & \\
& 0.05 & 1 & 29.4 & 39.4 & 23.2 & 30.7 \\
& & 2 & 20.9 & 36.4 & 19.4 & 25.6 \\
& 4 & 28.4 & 42.7 & 24.3 & 31.8 \\
\hline & & 26.2 & 39.5 & 22.3 & \\
\hline
\end{tabular}

1 Each figure is the computed mean of three replicates.

cantly further advanced in the high-water regime (table 7). Paraquat similarly produced an acid-phosphatase repression (tablc 7) which was highly significant at the close of the study (table 2). Again, the Paraquat effect was significantly further advanced within the high-water regime at 3 days.

The $\beta$-amylase found in sugarcane leaf tissue, extremely sensitive to factors such as nutrient supply, chemical ripening agents, and changes in illumination, was currently sensitive to high-water and Paraquat treatment (table 7). At each harvest the high-water plants contained significantly greater amounts of amylase when treated with Paraquat (table 2); as a function of water level, the amylase behavior had developed along significantly divergent slopes by the ninth day (fig. 3 ). This abundance of foliar amylase in plants no longer photosynthetically-active verifies earlier results obtained with an intermediate-water regime (7). In this connection Stokes and his collaborators (31) recently reported a starch decline in algae cells treated with Diquat.

Variable water and Paraquat treatments produced few persistent enzyme trends within immature storage tissue (table 8). Paraquat lowered invertase content as a main effect which conformed with earlier observations $(8,9,11)$. The Paraquat action was particularly severe in the low-water regime. Presumably, the greater abundance of invertase within the high-water regimes made possible an accelerated inversion of stored sucrose. The attendant sucrose losses correlate closely with increased green weights (table 4) and sucrose gains within the low-water regimes (table 5). Con- 
sistent with this are the findings by Hatch and Glasziou (25) showing that invertase levels and rates of internode expansion are linearly related in sugarcane given adequate water supply.

$\beta$-amylase was the only storage-tissue enzyme significantly repressed by high water, an effect which persisted at every harvest among the Paraquat-free plants (table 3). Paraquat alleviated this repression without producing large amylase increases such as those found in leaf tissue.

Previous work revealed large peroxidase increases in cane tissues treated with Paraquat $(8,9)$, a response possibly linked with plant efforts to destroy peroxides generated through bipyridyl action (17). In the present

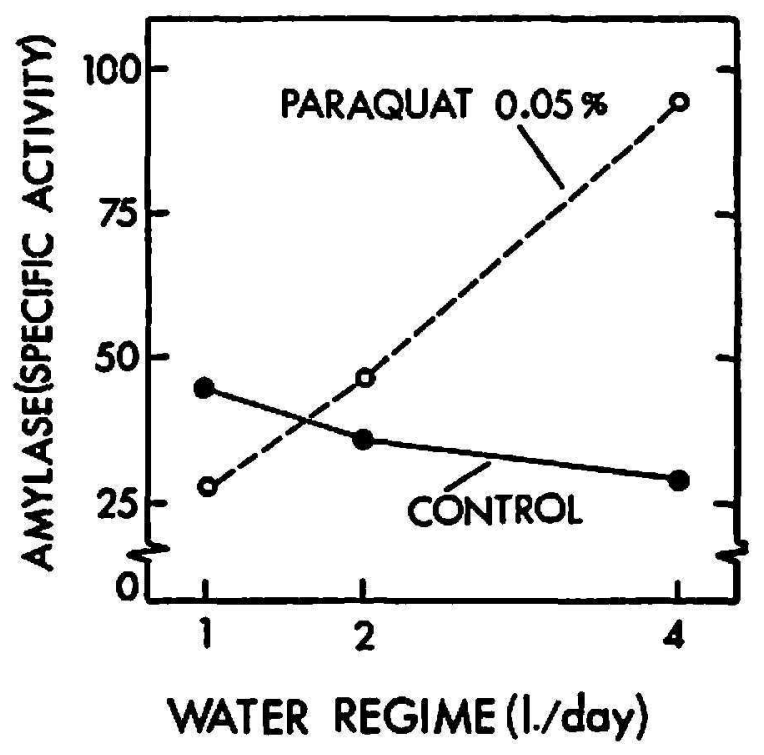

Fra. 3.-Foliar amylase content of immature sugarcane given variable water supply in sand culture and sprayed with an aqueous Paraquat solution. Water regime exerted a pronounced effect on the desiccant-induced enzyme increases.

study peroxidase was similarly increased by Paraquat as a main effect (table 8). The increase was most pronounced among low-water plants, with mean differences being significant at the second and third harvests (table 3).

With reference to ATP-ase and acid phosphatase, very few treatment effects were found in immature storage tissue (table 3). This contrasts sharply with leaf tissues where acid phosphatase and ATP-ase were severely suppressed by Paraquat. It is highly improbable that Paraquat action was localized in the leaves since invertase was clearly affected by the herbicide in immature storage tissue. More likely, the acid phosphatase and ATP-ase systems affected by Paraquat are situated in chloroplasts and catalyze reactions associated with the photosynthetic unit. Their counterparts in immature storage tissue are presumably localized in mitochondria and catalyze metabolic reactions, in effect being different enzymes performing similar work roles. 
TABLe 8.-Specific activity values for immalure storage tissue enzymes of sugarcane supplied with variable waler in sand culture and sprayed with variable Paraquat

\begin{tabular}{|c|c|c|c|c|c|c|}
\hline \multirow{2}{*}{ Enzyme } & \multirow{2}{*}{$\begin{array}{l}\text { Paraquat } \\
\text { (Percent } \\
\text { solution) }\end{array}$} & \multirow{2}{*}{$\begin{array}{l}\text { Water } \\
\text { (Liter/ } \\
\text { day) }\end{array}$} & \multicolumn{3}{|c|}{ Days after Paraquat application- } & \multirow{2}{*}{ Mean } \\
\hline & & & 1 & 3 & 9 & \\
\hline \multirow[t]{8}{*}{ Acid-phosphatase } & 0 & 1 & 43.9 & 42.1 & 32.8 & 39.6 \\
\hline & & 2 & 38.5 & 52.4 & 43.2 & 44.7 \\
\hline & & 4 & & 49.8 & 46.1 & 46.0 \\
\hline & Mean & & 41.5 & 48.1 & 40.7 & \\
\hline & 0.05 & 1 & 36.2 & 35.1 & 52.3 & 41.2 \\
\hline & & 2 & 38.4 & 40.9 & 46.7 & 42.0 \\
\hline & & 4 & 40.9 & 41.2 & 45.0 & 42.3 \\
\hline & Mean & & 38.5 & 39.1 & 48.0 & \\
\hline \multirow[t]{8}{*}{ ATP-ase } & 0 & 1 & 45.1 & 44.6 & 38.9 & 42.8 \\
\hline & & 2 & 36.9 & 47.3 & 38.3 & 40.8 \\
\hline & & 4 & 38.4 & 45.8 & 40.6 & 41.6 \\
\hline & Mean & & 40.1 & 45.9 & 39.3 & \\
\hline & 0.05 & 1 & 31.2 & 36.7 & 52.8 & 40.2 \\
\hline & & 2 & 34.3 & 37.5 & 44.3 & 38.7 \\
\hline & & 4 & 38.2 & 36.8 & 36.1 & 37.0 \\
\hline & Mean & & 34.6 & 37.0 & 44.4 & \\
\hline \multirow[t]{8}{*}{$\beta$-amylase } & 0 & 1 & 54.6 & 41.4 & 50.4 & 48.8 \\
\hline & & 2 & 36.3 & 39.6 & 37.5 & 37.8 \\
\hline & & 4 & 31.9 & 35.2 & 31.1 & 32.7 \\
\hline & Mean & & 40.9 & 38.7 & 39.6 & \\
\hline & 0.05 & 1 & 45.7 & 58.7 & 58.4 & 54.3 \\
\hline & & 2 & 44.3 & 54.1 & 58.9 & 52.4 \\
\hline & & 4 & 39.3 & 51.1 & 57.8 & 49.4 \\
\hline & Mean & & 43.1 & 54.6 & 58.3 & \\
\hline \multirow[t]{7}{*}{ Acid-invertase } & 0 & 1 & 9.2 & 13.7 & 5.4 & 9.4 \\
\hline & & 2 & 8.7 & 12.8 & 12.8 & 11.4 \\
\hline & & 4 & 14.6 & 14.4 & 13.4 & 14.1 \\
\hline & Mean & . & 10.8 & 13.6 & 10.5 & \\
\hline & 0.05 & 1 & 3.1 & 3.4 & 8.4 & \\
\hline & & 2 & 6.5 & 6.1 & 7.7 & 6.8 \\
\hline & & 4 & 5.7 & 6.7 & 8.3 & 6.9 \\
\hline
\end{tabular}


TABLE 8-Continued

\begin{tabular}{|c|c|c|c|c|c|c|}
\hline \multirow{2}{*}{ Enzyme } & \multirow{2}{*}{$\begin{array}{l}\text { Paraquat } \\
\text { (Percent } \\
\text { solution) }\end{array}$} & \multirow{2}{*}{$\begin{array}{l}\text { Water } \\
\text { (Liter/ } \\
\text { day) }\end{array}$} & \multicolumn{3}{|c|}{ Days after Paraquat application- } & \multirow{2}{*}{ Mean } \\
\hline & & & 1 & 3 & 9 & \\
\hline & Mean & & 5.1 & 5.4 & 8.1 & \\
\hline \multirow[t]{4}{*}{ Peroxidase } & 0 & $\begin{array}{l}1 \\
2 \\
4\end{array}$ & $\begin{array}{l}21.3 \\
19.3 \\
23.8\end{array}$ & $\begin{array}{l}18.2 \\
25.0 \\
20.2\end{array}$ & $\begin{array}{l}17.6 \\
23.6 \\
30.2\end{array}$ & $\begin{array}{l}19.0 \\
22.6 \\
24.7\end{array}$ \\
\hline & Mean & & 21.4 & 21.1 & 23.8 & \\
\hline & 0.05 & $\begin{array}{l}1 \\
2 \\
4\end{array}$ & $\begin{array}{l}27.1 \\
33.3 \\
32.0\end{array}$ & $\begin{array}{l}32.4 \\
29.1 \\
39.7\end{array}$ & $\begin{array}{l}44.6 \\
32.1 \\
37.6\end{array}$ & $\begin{array}{l}34.7 \\
31.5 \\
36.4\end{array}$ \\
\hline & Mean & & 30.8 & 33.7 & 38.1 & \\
\hline \multirow[t]{4}{*}{ Polyphenol-oxidase } & $\mathbf{0}$ & $\begin{array}{l}1 \\
2 \\
4\end{array}$ & $\begin{array}{l}21.0 \\
19.5 \\
22.7\end{array}$ & $\begin{array}{l}20.7 \\
26.2 \\
26.3\end{array}$ & $\begin{array}{l}19.3 \\
20.6 \\
24.2\end{array}$ & $\begin{array}{l}20.3 \\
22.1 \\
24.4\end{array}$ \\
\hline & Mean & & 21.0 & 24.4 & 21.3 & \\
\hline & 0.05 & $\begin{array}{l}1 \\
2 \\
4\end{array}$ & $\begin{array}{l}16.8 \\
20.3 \\
22.3\end{array}$ & $\begin{array}{l}20.3 \\
21.3 \\
31.0\end{array}$ & $\begin{array}{l}29.5 \\
22.1 \\
34.8\end{array}$ & $\begin{array}{l}22.2 \\
21.2 \\
29.4\end{array}$ \\
\hline & Mean & & 19.8 & 24.2 & 28.8 & \\
\hline
\end{tabular}

1 Each figure is the computed mean of three replicates.

Some evidence of Paraquat having affected ATP-ase in storage tissue was found 1 day after Paraquat treatment (table 8). Within the low-water regime, those plants treated with Paraquat contained significantly less ATP-ase than Paraquat-free plants (table 3). This response has no physiological significance, but it supports the thesis that water regime might temporarily modify a chemical desiccant's action.

\section{SUMMARY AND CONCLUSIONS}

Immature sugarcane was given variable-water regimes in sand culture and subsequently treated with a powerful desiccant, the bipyridylium herbicide Paraquat, applied as a 0.05-percent aqueous foliar spray. There were two objectives: (a) To evaluate the effects of water regime on sucroseenzyme relationships in desiccating sugarcane; and (b) to determine whether controlled water regimes could effectively modify Paraquat ac- 
tivity in sugarcane. Tissue samples were harvested for moisture, sugar and enzyme analyses at 1,3 and 9 days after Paraquat application.

Low water supply (1 liter per day) reduced total fresh weights and stalk weights, and increased sucrose content of immature storage tissue. Paraquat significantly lowered total fresh weights, stalk weights, sheath moisture and leaf sucrose by the 9-day harvest. Desiccant action was generally more rapid within the low-water regime. High- and intermediate-water regimes tended to modify Paraquat activity at 1 or 3 days, but its ultimate effects were comparable regardless of water regime. No evidence was found to support the theory that desiccating cane accumulates water as a function of continued water absorption when transpiration has ceased.

Acid invertase was suppressed by Paraquat, an effect consistent with earlier findings. The suppression was most severe in the low-water regime. Low-water supply significantly lowered invertase level but the response was not consistent at all harvests. Acid phosphatase and ATP-ase were severely repressed by Paraquat in leaves but not in immature storage tissue. An explanation was offered in terms of distinct chloroplast and mitochondrial enzymes rather than localized Paraquat action. For both enzymes the desiccant repression was significantly more severe in the high-water regime at 1 or 3 days, but water regime showed no effect at 9 days.

Paraquat significantly increased $\beta$-amylase in leaves (consistent with earlier studies), particularly within the high-water regime. In immature stem tissue $\beta$-amylase was repressed by high water in Paraquat-free plants. Paraquat eliminated the water effect. Peroxidase was increased in storage tissue by Paraquat. This response was statistically significant only under conditions of low-water supply.

It is concluded that variable water regimes can modify the rate of initial Paraquat activity in sugarcane; however, the ultimate effects of Paraquat will not be changed under conditions of thorough chemical application. Under field conditions of marginal chemical penetration, the plant's moisture status might play a more decisive role in determining the desiccant's effectiveness.

\section{RESUMEN Y CONCLUSIONES}

Caña inmadura cultivada en arena se sometió a regímenes variables de agua y posteriormente se trató con un desecante potente, el herbicida de bipiridilio Paraquat, aplicado en forma de aspersión foliar acuosa al 0.05 por ciento. Eran dos los objetivos: (a) Evaluar los efectos de un régimen de agua en las relaciones entre la sacarosa y las enzimas en la caña de azúcar en proceso de desecación; y (b) determinar si regímenes controlados de agua podrían modificar con efectividad la acción del Paraquat en la cafia de azúcar. Se tomaron muestras del tejido para hacer análisis del contenido de humedad, azúcar y enzimas al primero, tercero y noveno día posteriores a la aplicación del Paraquat. 
El suministro de un bajo nivel de agua (1 litro por día) redujo el peso fresco total y el peso de la caña molturable, y aumentó el contenido de sacarosa en el tejido reservante tierno. El Paraquat bajó significativamente los pesos frescos totales de la caña, los pesos de la caña molturable, el contenido de humedad de la yagua y el contenido de sacarosa foliar a los 9 días. La acción desecativa fue generalmente más rápida en el régimen bajo de agua. Los regimenes intermedios y altos de agua tendieron a modificar la acción del Paraquat al primero o al tercer día, pero sus efectos esenciales fueron comparables independientemente del régimen de agua. No se encontró evidencia para apoyar la teoría de que la caña en proceso de desecación acumule agua como función de una continua absorción de agua una vez la traspiración ha cesado.

El Paraquat detuvo la invertasa ácida, efecto que es compatible con hallazgos previos. La detención fue mós crítica en el régimen bajo de agua. El suministro de un bajo nivel de agua disminuyó significativamente el nivel de la invertasa pero la respuesta no fue consistente en todas las cosechas. El Paraquat reprimí vigorosamente la fosfatasa ácida y la fosfatasa del ATP en las hojas, más no en el tejido reservante tierno. Se propuso una explicación en términos de que existen distintas enzimas en los cloroplastos y en el mitocondrio en vez de una acción localizada del Paraquat. La represión de ambas enzimas por el desecante fue significativamente más severa en el régimen de un alto nivel de agua al primero y tercer día, aunque el régimen de agua no demostró tener efecto alguno a los 9 días.

El Paraquat aumentó significativamente la $\beta$-amilasa en las hojas (compatible con estudios previos), en particular con un régimen alto de agua. Se reprimió la $\beta$-amilasa en el tejido del tallo inmaduro mediante un régimen alto de agua en aquellas plantas que no fueron tratadas con Paraquat. Sin embargo, el Paraquat evitó el efecto del agua. En el tejido reservante tierno el Paraquat aumentó la peroxidasa. Esta respuesta fue estadísticamente significativa solo bajo condiciones de un suministro bajo de agua.

Se concluye que los regimenes variables de agua pueden alterar la rapidez con que el Paraquat actúa en la caña de azúcar; sin embargo, los efectos finales del Paraquat no podrán cambiarse bajo condiciones en que la aplicación del producto químico es completa. Cuando la aplicación se hace en el campo, siendo marginal la penetración del agente químico, el factor de la humedad de la planta podría jugar un papel más decisivo en la determinación de la efectividad del desecante.

\section{LITERATURE CITED}

1. Akhavein, A. A., and Linscott, D. L., The dipyridylium herbicides, Paraquat and Diquat, Residue Review 23: 97-146, 1968.

2. Alexander, A. G., Hydrolytic proteins of sugarcane: The acid phosphatases, J. Agr. Univ. P.R. 49 (2) : 204-28, 1965.

3. - Hydrolytic proteins of sugarcane: The acid invertases, J. Agr. Univ. P.R. 49 (3) : 207-30, 1965.

4. - Hydrolytic enzymes of sugarcane: Amylase, J. Agr. Univ. P.R. 49 (3) : 30824, 1965.

5. —, Oxidizing enzymes sugarcane: Tyrosinase, J. Agr. Univ. P.R. 50 (2): 113-30, 1966.

6. - - Oxidizing enzymes of sugarcane : Peroxidase, J. Agr. Univ. P.R. 50 (1) : 36$52,1966$.

7. - The mode of action of chemical desiccants in sugarcane, $X$ Congreso Latinoamericano de Química, San José, Costa Rica, Febrero 1969. 
8. Alexander, A. G. and Montalvo-Zapata, R., Enzyme studies of sucrose decline in sugarcane desiccated with Paraquat, J. Agr. Univ. P.R. 53 (4) : 230-50, 1969.

9. - Enzymatic factors in the sucrose decline of sugarcane desiccated with Paraquat, Diquat and Dinitrobutylphenol, J. Agr. Univ. P.R. 54 (1): 28-49, 1970.

10. - The use of silicon to preserve sucrose in sugarcane desiccated with Paraquat and Diquat, J. Agr. Univ. P.R. 54 (2): 247-63, 1970.

11. - , and Montalvo-Zapata, R., Desiccation effects of Paraquat and Diquat on growth and photosynthetic processes of sugarcane, Proc. P.R. Sugar Technol. Assoc., 1970.

12. Alexander, A. G., Samuels, G., and Spain, G. L., Physiology of sugarcane under water stress: Invertase, ATP-ase, and amylase behavior in plants experiencing water deficiency, night flooding, and continuous flooding, J. Agr. Univ. P.R., 56 (2) : 115-33, 1972.

13. Alexander, A. G., Montalvo-Zapata, R., and Spain, G. L., Sugarcane flower control studies with Paraquat, gibberellic acid, and sodium metasilicate, (unpublighed data).

14. Ashton, F. M., Effects of a series of cycles of alternating low and high soil water contents on the rate of apparent photosynthesis in sugarcane, Plant Physiol. 31 : 266-74, 1956.

15. Bates, J. F., Preliminary trials with desiccants in sugarcane, Proc. 13th. Cong. Br. W. Ind. Sugar Technol. 43-8, 1960.

16. Bennun, A., and Avron, M., Light-dependent and light-triggered adenosine triphosphatases in chloroplasts, Biochem. Biophys. Acta 79:646-48, 1964.

17. Boon, W. R., The chemistry and mode of action of the bipyridylium herbicides Diquat and Paraquat, Focus (A Plant Protection information service), Plant Protection Ltd., Agricultural Division, Fernhurst, Haslemere, Surrey, England, 1966.

18. Cardini, C. E., Leloir, L. F., and Chiriboga, J., The biosynthesis of sucrose, J. Biol. Chem. 214: 149-55, 1955.

19. Chambers, G. M., The use of the bipyridils in sugarcane, Proc. 9th. Br. Weed Control Conf. 763-67, 1968.

20. Davidson, L. G., Effects of desiccants on sugarcane, Proc. Int. Soc. Sugar Cane Technol. 11: 319-23, 1962.

21. Evans, H., and Bates, J. F., Some observations on the incidence and prevention of flowering of sugarcane in Guyana, Proc. 17th. Cong. Br. W. Ind. Sugar Technol. 279-90, 1966.

22. Gosnell, J. M., and Thompson, G. D., The effects of Paraquat on the growth and yield of sugarcane, Proc. Int. Soc. Sugar Cane Technol. 12: 493-500, 1967.

23. Gumbs, F. A., Further work on Gramaxone as a desiccant, Proc. Br. West Ind. Sugar Technol. 2: 249-65, 1966.

24. Hartt, C. E., Effect of moisture supply upon translocation and storage of ${ }^{14} \mathrm{C}$ in sugarcane, Plant Physiol. 42: 338-46, 1967.

25. Hatch, M. D., and Glasziou, K. T., Sugar accumulation cycle in sugarcane. II. Relationship of invertase activity to sugar content and growth in storage tissue of plants grown in controlled environments, Plant Physiol. 38: 344-48, 1963.

26. Hill, R., and Walker, D. A., Pycocyanine and phosphorylation with chloroplasts, Plant Physiol. 34 : 240-45, 1959.

27. Jagendorf, A. T., and Avron, M., Cofactors and rates of photosynthetic phosphorylation by spinach chloroplasts, J. Biol. Chem. 231 : 277-89, 1958. 
28. Metcalf, R. L., The bipyridylium herbicides, Advances in Pest Control Research: 8, 127-235, 1968.

29. Petrack, B., Craston, A., Sheppy, F., and Farron, F., Studies on the hydrolysis of adenosine triphosphate by spinach chloroplasts, J. Biol. Chem. 240 (2) : 906-14, 1965.

30. Robson, J. W., and Procter, G. C., Paraquat as a herbicide and desiccant in tropical agriculture, World Crops 15 (6): 264, 1963.

31. Stokes, D.M., Turner, J. S., and Markus, K., The effects of the dipyridyl Diquat on the metabolism of Chlorella vulgaris. II. Effects of Diquat in the light on chlorophyll bleaching and plastic structure, Aust. J. Biol. Sci. 23: 265-71, 1970.

32. Sutherland, E. W., Cori, C. F., Haynes, R., and Olsen, N. S., Purification of the hyperglycemic-glycogenolytic factor from insulin and from gastric mucosa, J. Biol. Chem. 180: 825-37, 1949. 